\title{
DIFFERENT COURTYARDS - DIFFERENT INFLUENCE ON THE QUALITY OF LIFE OF THE LOCAL RESIDENTS? ANALYSIS IN THE POST-SOCIALIST CITY OF BRNO, CZECH REPUBLIC
}

\author{
Maxmilian WITTMANN, Gabriel KOPÁČIK, Antonín VAISHAR, Marcela PETROVÁ \\ KAFKOVÁ, Pavla KILNAROVÁ \\ Brno University of Technology, Czech Republic
}

\begin{abstract}
Can different courtyards influence the quality of life of the local residents in different ways? This study focuses on the comparison of the courtyards in closed urban blocks from the $19^{\text {th }}$ century, the courtyards in the socialist open prefab housing estates and the courtyards in the post-socialist housing development. The analysed courtyards are located in the Central European city of Brno, Czech Republic. The study analyses the satisfaction of the residents living around the courtyards with the social and environmental qualities of the courtyards. The satisfaction which subjectively reflects the quality of life was expressed by the residents in a questionnaire survey. The social parameters of the residents' communities were verified by the demographic data to identify the different demographic conditions. The results imply that a considerable impact on the quality of life should be ascribed to the courtyards in closed urban blocks. The research generated a secondary result too: the analysed buildings and courtyards in the socialist housing estates don't belong to the socially declining areas.
\end{abstract}

Key Words: courtyard, local residents, closed urban block, open housing estate, the postsocialist city.

\section{Introduction}

The courtyards represent a significant value in cities. These spaces represent a place where the residents living around the courtyard are in contact with the nature and other people. The courtyards also provide a certain level of privacy, different from the streets outside the residential buildings. This article analyses the influence of the courtyards on the quality of life of the residents in the post-socialist Central European city of Brno, in the Czech Republic. The study presents the outputs of a basic research.

The article focuses on the courtyards which are part of different urban planning conceptions. Each urban planning conception was typical for a different time period. The article compares the closed urban blocks from the $19^{\text {th }}$ century (the pre-socialist era), the open prefab housing estates development from the second half of the $20^{\text {th }}$ century (the socialist era), where the open spaces between the residential buildings fulfill the function of a courtyard (a courtyard is defined as a space that is predominantly, clearly bordered by structures - but there are often different situations in the prefab housing estates), and the closed or partially closed courtyards in the residential complexes built at the end of the $20^{\text {th }}$ century (the post-socialist era). These types of residential complexes occupy a prominent place in the spatial arrangement of the city of Brno and they are typical for the spatial development of the city during the mentioned time periods.

For the reason of methodological uniformity and brevity, this study understands the term courtyard more generally - it can cover the real courtyard and also the open space between the residential buildings. The character of a courtyard may have, as we suppose, an influence 
on the quality of life of the residents living around the courtyards. This quality may be monitored via the analysis of the residents' satisfaction with their courtyards. This satisfaction subjectively reflects the quality of life in the neighbourhood. The related aspects of the topic were explored by many authors as Sirgy and Cornwell (2002), Comstock et al. (2010), Zhang (2013), Abass and Tucker (2018). None of the mentioned studies investigates the different courtyards as a part of a different urban planning conception in a post-socialist city. The most similar methodological approach is used by Lovejoy et al. (2010), who examine the traditional environment and suburbs. Iñigo and Mace (2018) explore the perimeter block in the suburbs, while Douglas et al. (2018) analyse the inner city neighbourhood, the suburb and the peri-urban settlement. Many authors understand the residents' satisfaction as indicator of the quality of life (Ala-Mantila et al. 2018, Perucca 2018). Also, many authors study the quality of life using a questionnaire survey among the residents in the monitored locality (Alam and Amin 2018, Grinde et al. 2018, Low et al. 2018).

This study analyses the satisfaction of the residents via the results of the questionnaire survey in the social and hygienic field. Some authors studied the quality of life in a similar way (Zulaica and Oriolani 2018). In this study, the questions are used as partial indicators of the quality of life. Each partial indicator is evaluated according to the specific answer on the scale of 1-10 points. The sum of the points obtained for each answer represents the overall satisfaction.

The aim of this study is to analyse the quality of life expressed by the residents' satisfaction and to compare the results in correlation with the type of courtyard. But, can we really find some results influenced only by the character of the courtyards, not by the period in which they were built-up? It must be stated here that the results may be affected by the following fact. The period of socialism differs from the other periods; at that time, the prefab housing estates provided the only new possibility of living in cities for a large part of the population. Moving into the prefab housing estates was realized in one wave and it was not entirely a matter of free choice. But in the last 30 years (after the regime change in 1989), people can freely choose the type of housing and move away, so the social structure of the inhabitants in the prefab housing estates can be specific, mostly declining. The study explores this phenomenon with the analysis of the demographic parameters of the residents' community. These issues were studied by many authors (Martinez 2018, Sánchez et al. 2018). The study explores the following issues: the change in the number of residents, their level of employment end education and the ratio of children and seniors. The unfavourable findings may indicate a declining society, which may reduce the comparability of the results. Overall summarized, the demographic analysis of the residents' community can bring a secondary result and it may confirm or disprove the former assumption that many socialist prefab housing estates may become socially excluded localities. The demographic data were explored and compared for all the analysed communities of residents, while the data were obtained from the census in the year 2001 and 2011 (Czech Statistical Office 2016).

The results can have importance for the city management of Brno which is concerned with the indicators of satisfaction on the scope of the whole city (Brno 2017). The indicators evaluate, for example, the safety of streets and squares on the scale of 4 to 1 points. In contrast to the analysis performed by the city, this study examines in detail the indicators referring to the courtyards. The courtyards, as well as the streets and squares, are mostly maintained and owned by the city. On a European scale, the quality of life was dealt with by EUROSTAT (2013), whose research principles were the inspiration for the city of Brno and our study. Some authors follow up directly on the European research (Senlier et al. 2009, Slavuj 2012, Štreimikienè 2014).

The explored communities of residents are, in this study, understood from the sociological point of view as neighbourhoods. Such communities are characterized by specific relationships to the environment and specific internal social relationships. The neighbourhood represents a 
specific phenomenon whose demonstrations and needs are the wider basis for the questionnaire survey. That's why the phenomenon of the neighbourhood requires special theoretical explanation.

\section{Methodology}

\section{Theoretical basis of the questionnaire survey}

The neighbourhood is a geographically localized community within a city. Within the organism of a city, the neighbourhood can be defined in various ways. Our approach understands the neighbourhood as the courtyard with surrounding buildings used by the locally defined group of residents. This corresponds to Fowler's approach (2016) that, in his research in Seattle, identified the neighbourhood with a block of buildings. Benkő (2015), in his research of prefab housing estates in Budapest, considers a neighbourhood to be the link between the town and the individual buildings. Some authors (Barton and Grant 2015) consider the neighbourhood to be a suitable element of urban planning.

The neighbourhood includes social interaction, symbolic interaction, and the connection of the individuals with the people and the place (Foster-Fishman et al. 2007). It becomes a socializing space. From the social point of view, the research of courtyards represents a shift from the scale of the whole city, or quarter, to the microstructure of the city. Chapin (2011) calls the inner courtyards "pocket neighbourhoods": small communities in a big world. The community related to the courtyards resembles, to a certain level, a village community with all its advantages and drawbacks. In this way, the social advantages of the city might combine with the social advantages of the rural environment. If this is true, the spaces are very significant, especially within the densely inhabited areas of inner cities (Vasilevska 2012).

The impact of social contacts in a city is substantial. It contributes to the stabilization of the relationships in a community, to the integration of individuals into a society, and to a mutual understanding of people from various social groups. Apart from a simple information exchange, people may also discuss particular issues of neighbourhood life, mutual help, etc. In such a community, there arises a certain level of social control which may be used as a factor of increasing safety, for example, in terms of childcare and later protection from drug abuse (Ager 2008). On the other hand, this factor means the loss of anonymity which is negatively perceived by the young people.

The existence of useable courtyards may, under certain circumstances, prevent social exclusion as it theoretically enables social contacts among people who know themselves personally; so it may be supposed that they will have a better understanding of the individuals' problems, and they may help each other. Required are the physical characteristics of courtyards (the presence of equipment and greenery), and also the creation of an adequate social climate. An important issue is also the stability of the residents' community, in other words, if the community mainly consists of people who have been its members for a relatively long time, or if there is a frequent migration, and so on.

It is obvious that the courtyards may have a different meaning for each group of residents. They are significant for the senior residents for whom these spaces represent a significant opportunity for physical activity and social contacts (Sugiyama at al. 2009). For them, the immediate vicinity of their residence becomes of major importance (Vidovičová et al. 2014). Another group that very significantly uses the courtyards is represented by the children (Valentine and McKendrick 1997). The extent of using the spaces by children is to a certain level dependent on the character of the spaces. In their study of using these inner-city spaces, Taylor et al. (1998) showed that green spaces are used by children significantly more intensively. The use of outdoor spaces generally depends on the life style and social 
interaction. For those residents who use the spaces regularly, a high quality environment means a higher quality of life (Da Silva et al. 2012).

Courtyards might be places with lower safety. The cause might be the occurrence of alcoholism, homelessness, vandalism, or even criminality (Jayne et al. 2006). Cities intend to drive some social groups from the publicly accessible courtyards. Moreover, this tactic does not solve the problem, but it only drives the given social groups to another place where they may concentrate (ghettoization). Some groups may feel excluded from participation in public spaces (Madge 1997, Foster et al. 2010, Mak and Jim 2018). The usage of outdoor space is thus conditioned by the feeling of safety. The work of Francis (1989) was followed by other authors (Andrews and Gatersleben 2010, Vidovićová et al. 2014, Baran et al. 2018). Generally, the residents consider the urban environment to be safer in the case of small spaces, with greenery, trees and buildings in the background, than in the case of large densely planted areas (Jiang et al. 2014, Li et al. 2015, Chiang et al. 2017). As ambivalent, it is frequently considered the using of outdoor spaces by young people who, in order to feel safe, tend to gather into groups, which causes the feeling of lower safety for the rest of the users (Crawford and Flint 2009). So, the interests and needs of various social groups using the outdoor spaces might be under certain conditions contradictory. Nevertheless, this fact does not reduce the general importance of courtyards which may create a significant potential for the development of social relationships in the residents' community.

As it is obvious from the previous text, the safety of the courtyards may represent a risk for their social exclusion. The way and frequency of using the courtyards may also influence the development of social relationships in the neighbourhood (residents' community). And therefore this study uses the elimination of the risk of social exclusion while using the courtyards with two important framework indicators of the quality of life in the neighbourhood. The framework indicator called "relation to the place" illustrates the importance of internal links mentioned by some authors (Chapin 2011, Vasilevska 2012). The framework indicator "perception of hygienic parameters" is used in the study primarily to complement the objectively founded data. The framework indicators are divided into partial indicators - the questions evaluated by the specific answers in the questionnaire.

Additional notice: the residents' satisfaction can be influenced also by the environmental and economic characteristics of the courtyards. According to the existing research, some characteristics of the courtyards can influence their hygienic qualities. Urban greenery reduces the air temperature in the urban area (Bowler et al. 2010). Different forms of buildings help to mitigate the level of traffic-induced noise in the open space (Weber et al. 2014). There are other environmental factors as air pollution that have a strong influence on the health of the local communities and their social development (Coyle 2011). The very existence of the courtyards might also influence the prices of real estates in the locality. The basic environmental and economic data were verified in this study.

\section{Selection of locations and methods of data obtaining}

The study analyses the courtyards in the selected residential areas in Brno. The city of Brno, reaching almost 400000 inhabitants, is the second largest city in the Czech Republic and it represents a typical post-industrial, post-socialist city in Central Europe. In the case studies, thirteen courtyards were analysed. The courtyards as part of the following groups of buildings were analysed:

closed urban blocks from the 19th century - the pre-socialist era;

prefab housing estates built by a unified concrete panel technology in the socialist era; they typically consist of high-rise blocks, with an open urban planning conception; 
residential complexes built in the post-socialist era (after the year 1989).

All of the analysed places are well connected to the car and public transport and they have a standard technical infrastructure. But, none of the analysed courtyards is used for parking.

The overall satisfaction of the residents' community was investigated via the partial indicators represented by the questions in the questionnaire. The partial indicators are grouped in the framework indicators defined in the previous section. The survey was focused on the four above-mentioned groups of framework phenomena: risk of social exclusion; way and frequency of using the courtyards; perception of the hygienic qualities of the courtyards in comparison with the close street; and relation to the place and the neighbours.

The partial, individual, indicators reflect the performed questionnaire survey among the residents - in the buildings around the courtyards. A responsible (adult) person, representing the household, provided (filled in) the answers in the questionnaires. The questionnaire survey was performed in autumn 2016. In total, there were distributed almost 1800 questionnaires, and, out of these, $30-40 \%$ were completed for each building, within 2-3 weeks. Each case study included an average of 150 questionnaires distributed in the blocks where the residents allowed the survey. The exceptions were the smaller case studies BS6 (78 questionnaires) and BZ (50 questionnaires) where the questionnaires were distributed to almost every household in the block. The particular topics of the individual questions which are at the same time the indicators of sustainability are included in Table 2 in the Results section. The respondents selected from the precisely defined answers the one which corresponded to the reality the most. Each answer had a number of points on the scale 1-10. The 10 points in the questionnaire expressed the total absence of a negative phenomenon (e.g. manifestation of vandalism) or the total presence of a positive phenomenon (e.g. feeling safe) and the 1 point in the questionnaire expressed the opposite principle. The 5 points expressed the almost standard rating, the 6 points expressed the slightly above-standard rating (the people have to express a slightly negative or positive opinion). The 10 point scale also reflects the methodology of the city of Brno, which also uses a point scale with an even number of rating levels. The city uses the scale of 4-1 points, where the 4 points express the worst rating and the 1 point expresses the best rating. This study uses a more detailed point scale where the higher points level express the higher rating - the higher satisfaction.

The questions concerned with the frequency of the phenomena had the following answers: 10 points referred to the more than 10 minutes everyday occurrence of the phenomenon, 5 points referred to an occurrence of two days in a week, and 1 point referred to the total absence of the phenomenon (the answers also specified the frequency of the phenomena between the given limits). The question on the diversity of activities offered 10 types of activities and each one was awarded 1 point (going home, going for a walk, parking of a car, relaxing, walking the dog, going shopping, meeting the neighbours, meeting strange people, working in the garden, other activity). The questions on using the space according to gender was awarded 10 points if the respondent assumed that the courtyard was used by the same number of men and women, 5 points corresponded to the almost 50 percent deviation and 1 point corresponded to the exclusive using by men or by women (the answers specified also the character of the phenomenon between the given limits). The "longtime residency" was awarded 10 points in the case when the respondent lived in the same house for 10 or more years. The point evaluation which surveys the development in and after the year 2011 (the year when the census was performed) declined in a linear manner to number 1 . The question on the participation in the maintenance of the courtyards was awarded 10 points when the respondent was, without doubt, ready to pay for the maintenance of the courtyard apart from the common fee to the city which owns and maintains the courtyard. The amount of additional fee was estimated at $5 \%$ of the housing costs. The point evaluation declined linearly through the neutral feeling of 5 points to the total unwillingness awarded 1 point. 
The potential of the social development of the residents' community (neighbourhood) was verified by its demographic parameters which were obtained from the census. This analysis is based particularly on the census performed in 2011, or as a comparison of the census in 2001 and 2011 (Czech Statistical Office 2016). The census provides demographic data about particular buildings. The Czech database does not provide the statistics of the income structure which is usually substituted by the data on the unemployment and education structure of the residents being older than 15 years. The potential of the social sustainability of the residents' community is summarised in Table 1 . The table presents percent data on: the change in the number of the residents between the year 2001 and 2011; the ratio of the number of residents older than 65 years and younger than 15 years in the year 2011; the number of residents with higher education than primary school (at the same and higher level than the so-called ISCED 3 ) in the year 2011; and the ratio of the unemployed persons among the economically active residents in the year 2011.

The point evaluation and its commentary are part of the Results section. The average values for each case study and for each question are summarized in Table 2. The total number of points for the framework indicators is shown in Fig. 8. The total of points for all questions and the percent ratio of the awarded points to their maximum are shown in Fig. 9.

Additional notice: the analysis of the residents' community described in the previous text was added by the verification of the basic parameters in the environmental and economic field. Certified instruments (Minikin RTHi/QTHi) were used to measure the levels of temperature and noise; the measurements were performed simultaneously in the courtyards and in the streets. The level of air pollution for each locality was taken from the website (Brno 2010). The real estate agency Real Spektrum (2016) provided the real estate prices.

\section{Surveyed courtyards}

The surveyed courtyards (spaces between the residential buildings) presented in this study are situated in the following localities of Brno (Fig. 1):

- in the closed urban blocks in the north of the city centre of Brno (locality BS);

- in the prefab housing estate in Brno-Vinohrady (BV);

- in the prefab housing estate in Brno-Lesná (BL);

- in the residential complex in Brno-Majdalenky (BM);

- in the residential complex in Brno-Žebětín (BZ).

In the "BS" and "BV" localities, more than one courtyard was analysed (six and four, respectively).

\section{Courtyards in the closed urban blocks near the city centre of Brno (BS1 - BS6 spaces)}

The courtyards inside the closed urban blocks of the four- to six-floor residential buildings from the second half of the $19^{\text {th }}$ century are located in the north of the city centre of Brno. The research focused on six case studies in total which are labelled BS1 - BS6 (Fig. 2, Fig. 3). The courtyards with a significant proportion of well-maintained trees, grass and other greenery are not, with the exception of BS3, accessible to the public. The BS1 - BS6 courtyards lie in the plane, and they are partly covered with small gardens at the houses used by some of the residents and partly with large recreational places accessible to all the residents. The recreational places consist of quality greenery and playgrounds, and they are mainly equipped with benches. There is no night lighting in the courtyards. The B6 consists of two very small courtyards located approximately 300 m southeast of B1 - B5; they are very small and they are predominantly used as storing space of the restaurants and shops situated on the ground floor. All courtyards are located on the plots owned by the city which maintains them. The adjoining buildings are predominately owned by the associations of flat owners. The locality represents 
an attractive place of housing which is undergoing continuous renovations. The sale and rent prices of housing and commercial space in the locality are above the average within the city of Brno. The BS6 space is an exception as the prices of housing are below the prices of BS1 BS5 and the prices of commercial spaces are at the same or at a higher level than BS1 - BS5 spaces.

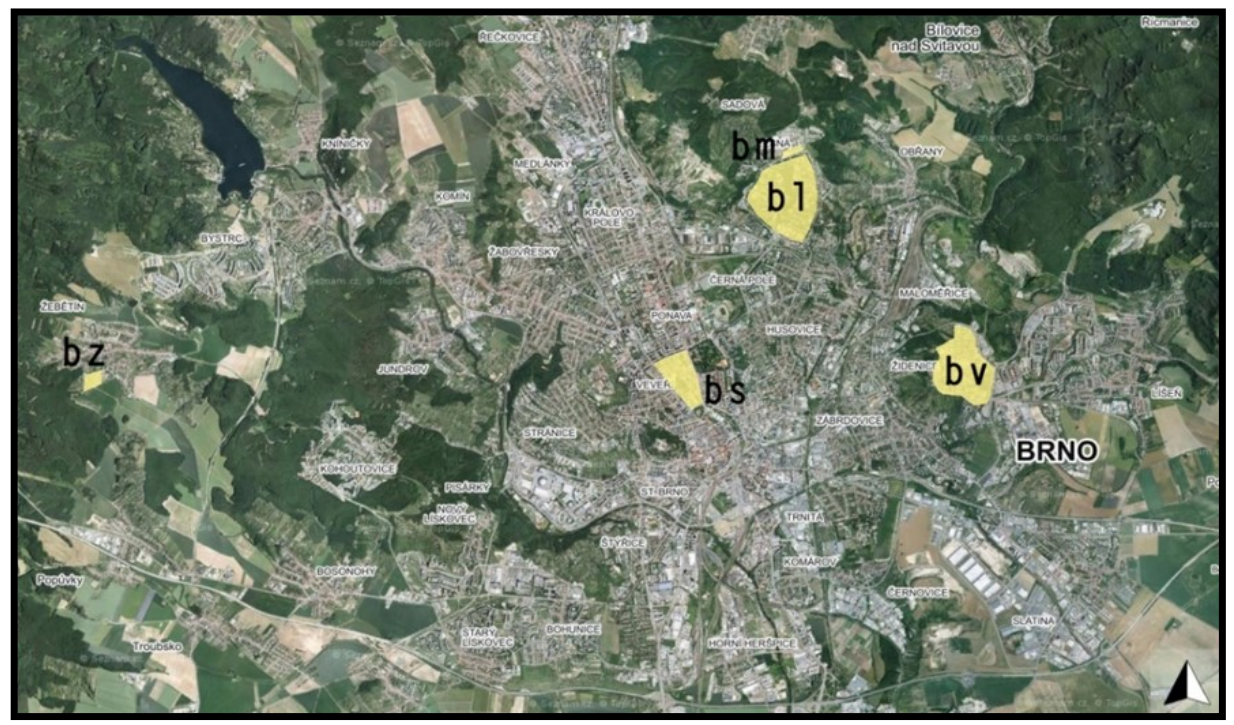

Fig. 1 - Selected localities of Brno Source: OpenStreetMap 2016

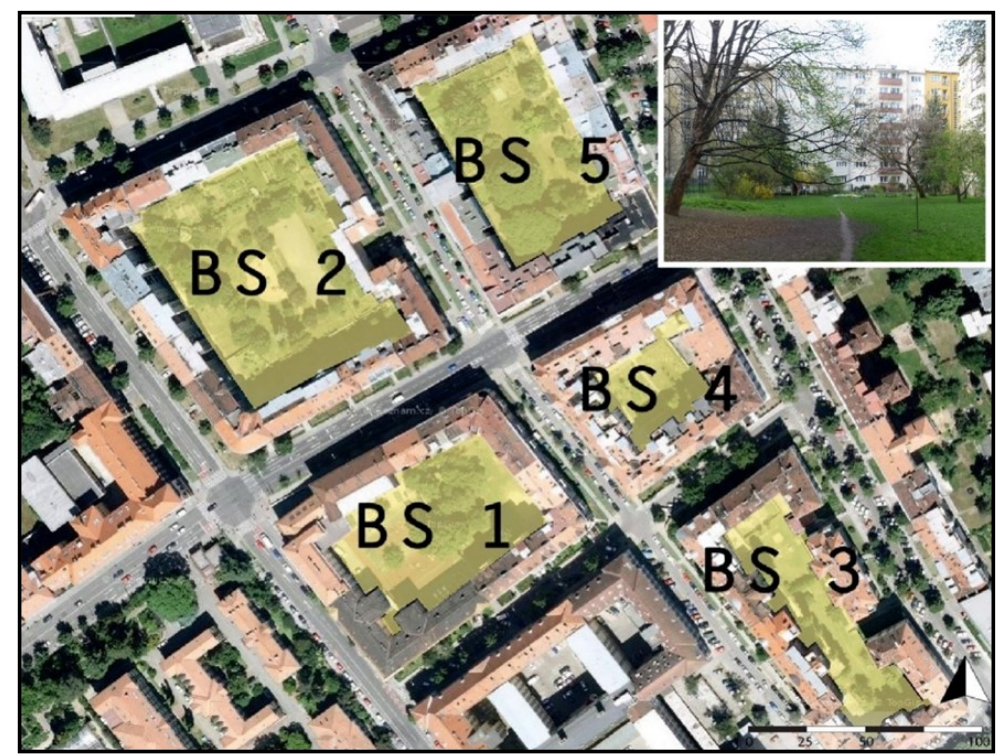

Fig. 2 - The geographical borders of case studies BS1 - BS5 Source: OpenStreetMap 2016; Photograph of the BS5 courtyard by the authors 


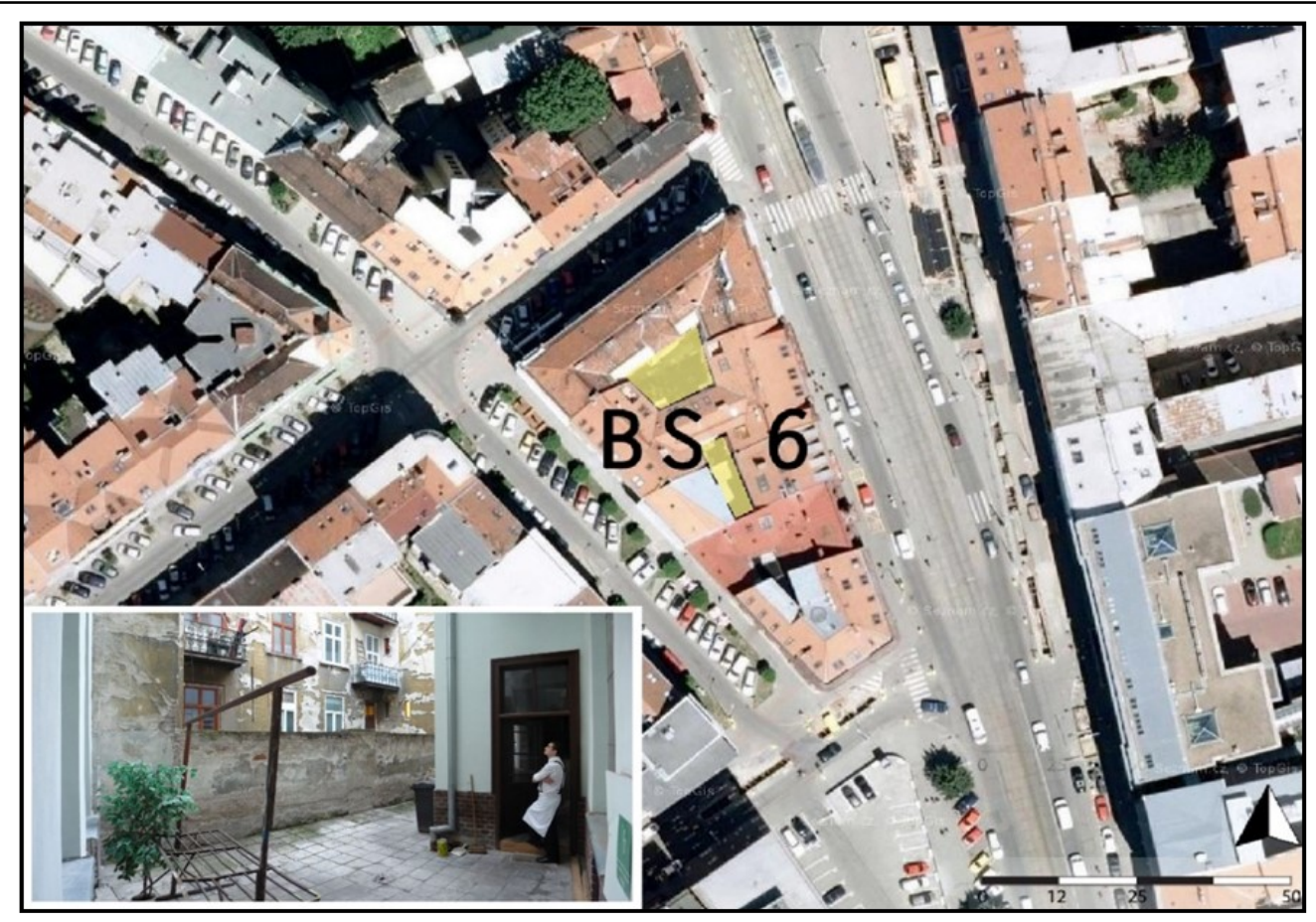

Fig. 3 - The geographical borders of the BS6 case study

Source: OpenStreetMap 2016; Photograph of larger BS6 courtyard by the authors

The courtyards in the prefab housing estate in Brno-Vinohrady (BV1 - BV4)

The survey was performed on the four spaces accessible for public in the prefab housing estate in Brno-Vinohrady. The surveyed spaces labelled BV1 - BV4 are located on the plots owned by the city which maintains them (Fig. 4). BV1 labels Pálavské náměstí [Pálava square] which is actually a park with a significant proportion of well-maintained trees, grass and other greenery. The park is located in front of a four-floor apartment building with an underground parking. On the north side of the park (behind the road), there is a one-floor commercial building. BV2 labels a space where greenery consists of only two trees. It is the space between the above-mentioned residential building and a commercial building with shops. BV3 labels a space with a significant amount of well-maintained trees, grass and other greenery. It surrounds a twelve-floor residential building owned by an association of flat owners. The BV4 labels the courtyard with a significant amount of well-maintained trees, grass and other greenery. The space is surrounded by two residential buildings owned by the associations of flat owners; in the south, it is a four-floor building, and, in the north, it is an eight-floor building. The BV1 - BV4 courtyards lie in the plane. They are mostly used as recreational places with the function of pedestrian corridors accessible to the public. The places consist of quality greenery, and they are equipped mainly with quality benches and trash cans. The night lighting is located in the BV1 and BV2 courtyards only. The prefab housing estate was completed in the socialist era in the second half of the 1980s. The housing in this locality is popular thanks to its vast services as well as affordable prices (average city-level prices). The locality is undergoing continuous renovations. 


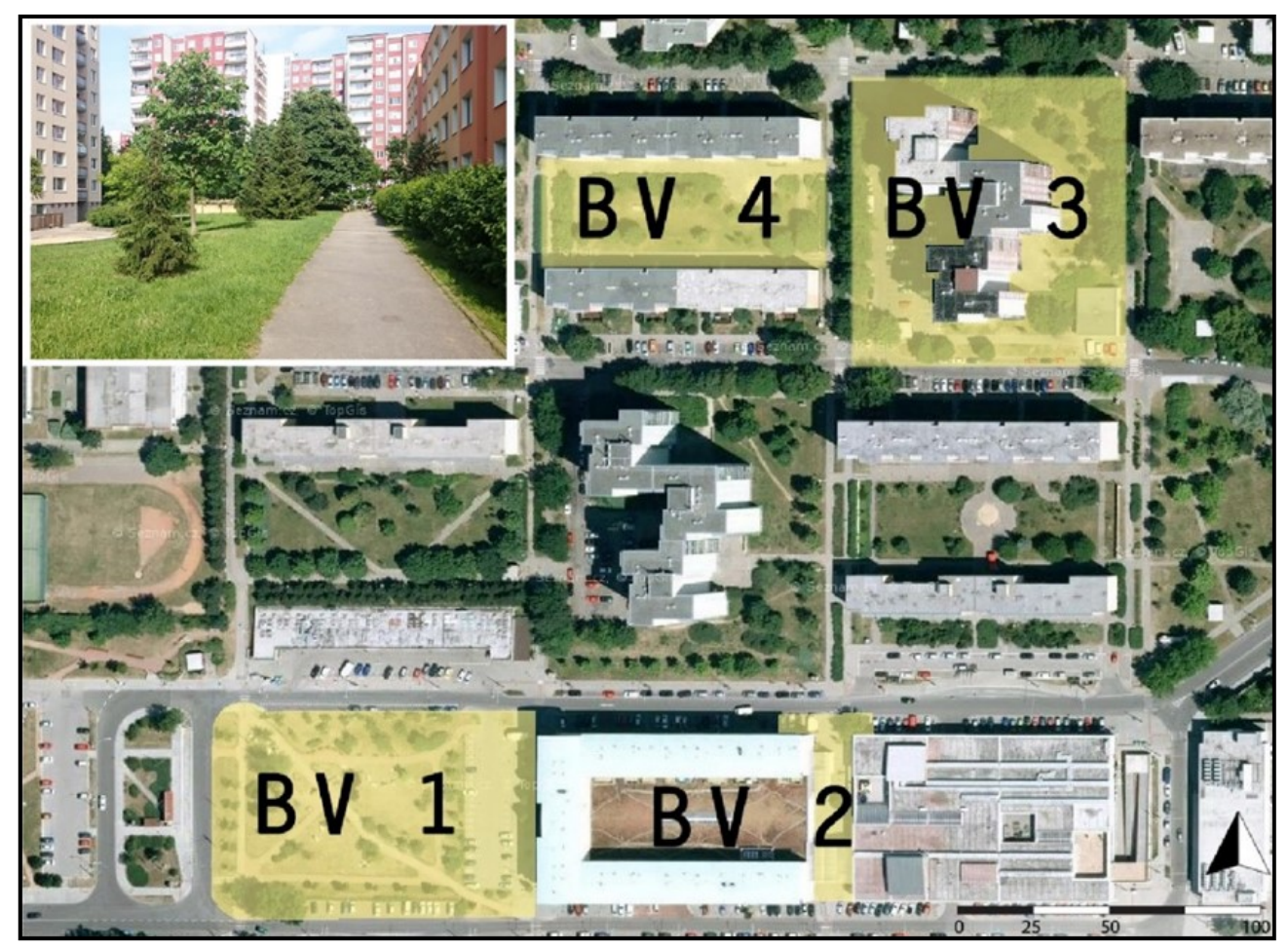

Fig. 4 - The geographical borders of case studies BV1 - BV4

Source: OpenStreetMap 2016; Photograph of the BV4 courtyard (BV3 in the background) by the authors

The courtyard in the prefab housing estate in Brno-Lesná (BL)

The survey was focused on the BL public space between two eight-floor apartment buildings in the prefab housing estate in Brno-Lesná (Fig. 5). This vast space with a maximum proportion of well-maintained trees, grass and other greenery is located on the plots owned by the city which maintains them. The courtyard lies in the plane. It is used as recreational place accessible to the public. The place is equipped mainly with quality benches and trash cans. The night lighting is located in the BL courtyard. The surrounding buildings are owned by an association of flat owners. The housing estate, which was conceived as a complex of buildings in the greenery, was completed in the socialist era, during the second half of the 1960s. Housing in Brno-Lesná estate is popular thanks to the natural environment and extensive greenery. The professionals evaluate it as the best prefab housing estate in Brno. It is inspired by the Tapiola housing estate in Helsinki, Finland. There is a live discussion about its potential to become a protected monument (Brněnský Deník [Brno Daily] 2009).

\section{The courtyard in the residential complex in Brno-Majdalenky (BM)}

The surveyed space accessible for public adjoins to eight-floor buildings and it is located to the north of the prefab housing estate Brno-Lesná, in a residential complex Majdalenky, at the edge of the city of Brno. The surveyed BM space, with a low proportion of greenery, is located on the plots owned by the city which maintains it (Fig. 6). The courtyard lies in the plane. It could be used more intensively as recreational or meeting place for the residents. The place 


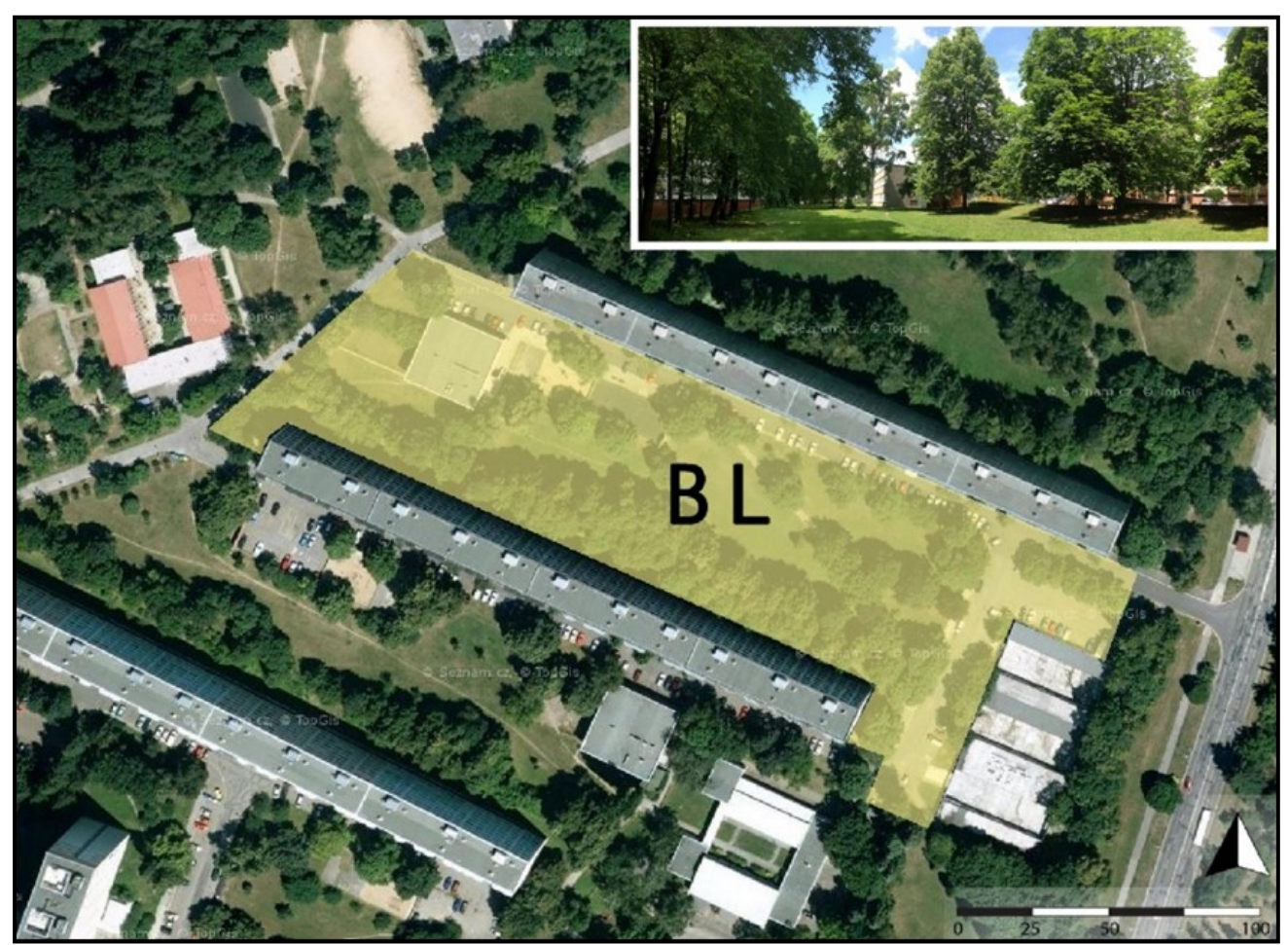

Fig. 5-The geographical borders of BL case study Source: OpenStreetMap 2016; Photograph of the BL courtyard by the authors

has no equipment (like benches), the greenery is represented by the grass and some trees. There is no night lighting located in the BM courtyard. The Majdalenky residential complex mostly consists of cooperative buildings with built-in parking. The complex was completed at the end of the 1990s.

The courtyard in the residential complex in Brno-Žebětín (BZ)

The BZ courtyard is operationally accessible to the public, but its closed space form indicates more of a private character of the courtyard (Fig. 7). The courtyard is part of a new residential complex called Pod Kněžským hájkem which is located in the suburbs of Brno, in the city part called Brno-Žebětín. The BZ courtyard has a large proportion of well-maintained greenery (grass and trees). It is owned by the city which maintains it. The courtyard lies on a mild slope. It is used as recreational place especially for the residents. The place is equipped with children playground and quality benches. There is no night lighting located in the BZ courtyard. A small part of the area adjoining the ground floor flats is fenced and it is used as private gardens of the flats owners. The courtyard is surrounded by three-floor cooperative buildings. Two buildings contain an underground parking garage. The residential complex was completed around the year 1999 . 


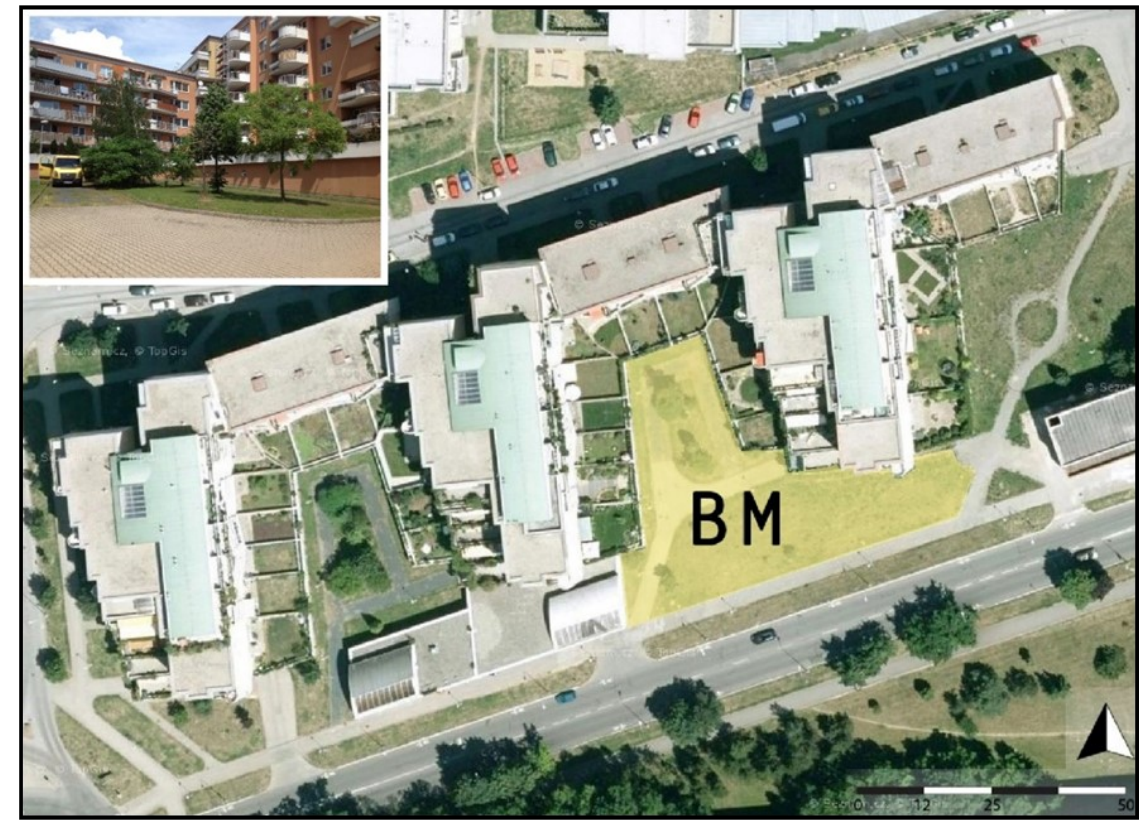

Fig. 6 - The geographical borders of BM case study

Source: OpenStreetMap 2016; Photograph of the BM courtyard by the authors

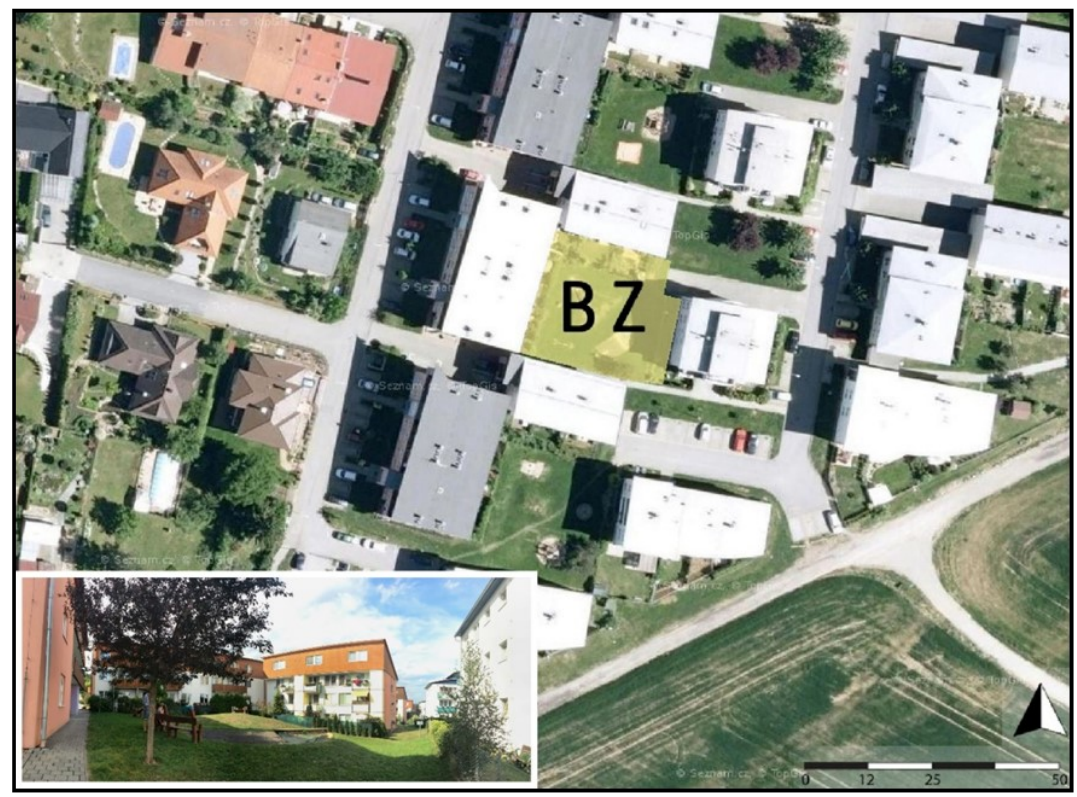

Fig. 7 - The geographical borders of BZ case study Source: OpenStreetMap 2016; Photograph of BZ courtyard by the authors 
Maxmilian WITTMANN, Gabriel KOPÁČIK, Antonín VAISHAR, Marcela PETROVÁ KAFKOVÁ, Pavla KILNAROVÁ

\section{Results}

All the results of the analysis are presented in the Tables 1, 2, Fig. 8, Fig. 9 and in the commentaries following the tables. The tables reflect the methodology described in the appropriate section.

Table 1

Demographic data of the analysed case studies according to the census in 2001 and 2011

\begin{tabular}{|c|c|c|c|c|c|c|c|c|c|c|c|c|c|}
\hline \multirow{2}{*}{$\begin{array}{l}\text { Demographic } \\
\text { data }(\%)\end{array}$} & \multicolumn{13}{|c|}{ Case study } \\
\hline & BS1 & BS2 & BS3 & BS4 & BS5 & BS6 & BV1 & BV2 & BV3 & BV4 & BL & BM & $B Z$ \\
\hline $\begin{array}{l}\text { Change in the } \\
\text { number of resi- } \\
\text { dents (between } \\
2001 \text { and 2011) }\end{array}$ & +2.0 & -3.5 & $-4,6$ & -4.0 & -2.2 & -27.0 & -1.0 & -5.2 & -4.1 & -3.1 & -0.5 & $+2,5$ & +1.8 \\
\hline $\begin{array}{l}\text { The ratio of resi- } \\
\text { dents older than } \\
65 \text { and younger } \\
\text { than } 15 \text { years } \\
(2011)\end{array}$ & $59 / 41$ & $62 / 38$ & $58 / 42$ & $56 / 44$ & $59 / 41$ & $66 / 33$ & $35 / 65$ & $32 / 68$ & $29 / 71$ & $32 / 68$ & $53 / 47$ & $26 / 74$ & $32 / 68$ \\
\hline $\begin{array}{l}\text { Education higher } \\
\text { than ISCED } 3 \\
\text { (2011) }\end{array}$ & 92.7 & 86.3 & 88.0 & 82.7 & 86.4 & 87.4 & 83.5 & 97.3 & 85.9 & 84.3 & 83.2 & 88.1 & 91.8 \\
\hline $\begin{array}{l}\text { Unemployment } \\
\text { (2011) }\end{array}$ & 5.3 & 4.6 & 5.6 & 5.4 & 6.7 & 3.6 & 7.2 & 4.4 & 8.1 & 8.9 & 4.9 & 3.8 & 3.2 \\
\hline $\begin{array}{l}\text { Complementary } \\
\text { data - total num- } \\
\text { ber of residents } \\
(2011)\end{array}$ & 229 & 638 & 431 & 313 & 546 & 134 & 356 & 148 & 425 & 397 & 1074 & 263 & 125 \\
\hline
\end{tabular}

Source: Czech Statistical Office 2016

Table 1 presents the following findings based on the census data in 2001 and 2011. Above all, it is necessary to state that none of the surveyed areas is immediately endangered by demographic decline. The exception is represented by the BS6 case-study where, between 2001 and 2011, the number of residents decreased by $27 \%$. The average decrease of the residents in the city, as a result of the suburbanization process, was of $3.8 \%$. In all cases, the surveyed level of residents' education corresponds more or less with the average in the Czech Republic (88.1\% higher level than ISCED3). The unemployment among the economically active residents corresponds more or less with the average of the Czech Republic in 2011 $(5.7 \%)$. A remarkable fact is the ratio of the residents older than 65 and younger than 15 years. In the prefab housing estate of Brno Vinohrady (BV1 - BV4), as well as in the new blocks in the locality BM and BZ, there is a considerable predominance of children in contrast to the BS1 BS6 localities (Czech Statistical Office 2016), which disproves the hypothesis of a distinctive danger of depopulation for the prefab housing estates in the Czech Republic.

Table 2 shows that the BS1 - BS5 courtyards are considered as highly safe during day and night, with the exception of dark for the BS6 small courtyards. In comparison to the other surveyed courtyards, the BS1 - BS5 are closed and clearly arranged. According to the respondents, the BZ small courtyard is also safe. In this context, it is interesting to compare the 
Different Courtyards - Different Influence on the Quality of Life of the Local Residents? Analysis in the Post-Socialist City of Brno, Czech Republic

Table 2

The results of the questionnaire survey: the framework indicators and the average point values of the partial indicators for each question and the case study on the 1-10 points scale

\begin{tabular}{|c|c|c|c|c|c|c|c|c|c|c|c|c|c|c|}
\hline \multirow{2}{*}{$\begin{array}{l}\text { Framework } \\
\text { indicator }\end{array}$} & \multirow{2}{*}{$\begin{array}{l}\text { Partial indica- } \\
\text { tor - a ques- } \\
\text { tion in the } \\
\text { questionnaire }\end{array}$} & \multicolumn{13}{|c|}{ Case study } \\
\hline & & BS1 & $\begin{array}{c}\text { BS } \\
2\end{array}$ & BS & $\begin{array}{c}\text { BS } \\
4\end{array}$ & $\begin{array}{c}\text { BS } \\
5\end{array}$ & $\begin{array}{c}\text { BS } \\
6\end{array}$ & BV & $\begin{array}{l}\text { BV } \\
2\end{array}$ & $\begin{array}{c}\text { BV } \\
3\end{array}$ & $\begin{array}{c}\text { BV } \\
4\end{array}$ & BL & BM & $B Z$ \\
\hline \multirow{6}{*}{$\begin{array}{l}\text { Elimination } \\
\text { of risk of } \\
\text { social exclu- } \\
\text { sion }\end{array}$} & $\begin{array}{l}\text { feeling of safety } \\
\text { in the courtyard } \\
\text { by day }\end{array}$ & 8.1 & 8.7 & 7.7 & 9.6 & 8.5 & 5.3 & 5.3 & 3.4 & 5.7 & 6.0 & 7.7 & 4.6 & 7.8 \\
\hline & $\begin{array}{l}\text { feeling of safety } \\
\text { in the courtyard } \\
\text { by night } \\
\end{array}$ & 7.6 & 7.8 & 6.2 & 8.1 & 7.9 & 3.9 & 5.3 & 2.8 & 4.8 & 5.3 & 5.7 & 3.6 & 6.3 \\
\hline & $\begin{array}{l}\text { display of van- } \\
\text { dalism }\end{array}$ & 8.5 & 8.8 & 7.8 & 8.5 & 8.9 & 6.0 & 7.1 & 5.3 & 5.0 & 6.2 & 6.0 & 5.1 & 7.0 \\
\hline & $\begin{array}{l}\text { traces of using } \\
\text { drugs }\end{array}$ & 8.9 & 9.0 & 8.5 & 8.9 & 9.0 & 8.0 & 7.2 & 7.1 & 8.0 & 6.5 & 6.1 & 7.5 & 8.9 \\
\hline & $\begin{array}{l}\text { groups drinking } \\
\text { alcohol }\end{array}$ & 8.1 & 7.5 & 8.1 & 7.8 & 9.5 & 7.5 & 5.0 & 3.0 & 7.1 & 5.5 & 8.2 & 9.5 & 9.0 \\
\hline & $\begin{array}{l}\text { untrustworthy } \\
\text { strange per- } \\
\text { sons }\end{array}$ & 9.0 & 8.2 & 6.1 & 8.4 & 9.2 & 7.0 & 6.8 & 3.6 & 6.2 & 5.5 & 6.6 & 6.1 & 9.6 \\
\hline \multirow[t]{5}{*}{$\begin{array}{l}\text { Using of } \\
\text { courtyard }\end{array}$} & $\begin{array}{l}\text { diversity of ac- } \\
\text { tivities }\end{array}$ & 5.7 & 4.7 & 4.7 & 4.3 & 4.5 & 1.5 & 6.8 & 3.9 & 5.4 & 4.9 & 5.8 & 3.6 & 4.5 \\
\hline & $\begin{array}{l}\text { frequency of } \\
\text { use }\end{array}$ & 5.8 & 5.1 & 6.7 & 5.3 & 6.0 & 8.6 & 7.2 & 8.7 & 7.7 & 5.6 & 8.4 & 3.9 & 5.2 \\
\hline & $\begin{array}{l}\text { frequency of } \\
\text { meetings with } \\
\text { the neighbours } \\
\end{array}$ & 7.0 & 7.9 & 6.5 & 7.1 & 8.2 & 1.1 & 6.1 & 3.8 & 4.1 & 6.5 & 3.5 & 2.9 & 7.8 \\
\hline & $\begin{array}{l}\text { gender diversity } \\
\text { of the courtyard } \\
\text { users } \\
\end{array}$ & 9.1 & 7.5 & 7.8 & 7.5 & 9.0 & 2.5 & 7.5 & 5.0 & 5.0 & 5.5 & 9.5 & 5.0 & 7.5 \\
\hline & $\begin{array}{l}\text { courtyard co- } \\
\text { vers the needs }\end{array}$ & 6.7 & 7.5 & 5.4 & 7.1 & 7.2 & 2.6 & 5.9 & 1.5 & 4.7 & 4.7 & 8.0 & 3.4 & 5.7 \\
\hline \multirow[t]{4}{*}{$\begin{array}{l}\text { Perception } \\
\text { of hygienic } \\
\text { parameters }\end{array}$} & $\begin{array}{l}\text { high tempera- } \\
\text { ture }\end{array}$ & 6.8 & 6.2 & 6.7 & 6.0 & 7.2 & 7.6 & 5.8 & 5.2 & 5.9 & 6.3 & 8.5 & 5.6 & 7.7 \\
\hline & noise & 6.0 & 7.9 & 8.0 & 7.5 & 7.0 & 8.1 & 6.1 & 4.1 & 5.9 & 6.8 & 8.0 & 4.5 & 7.2 \\
\hline & smell & 6.5 & 5.8 & 5.9 & 7.3 & 6.0 & 7.0 & 5.9 & 5.1 & 6.0 & 6.2 & 8.3 & 4.1 & 6.5 \\
\hline & dust & 8.5 & 7.5 & 5.8 & 6.2 & 7.8 & 8.1 & 5.7 & 4.2 & 5.8 & 6.7 & 7.2 & 4.0 & 6.8 \\
\hline \multirow[t]{5}{*}{$\begin{array}{l}\text { Relation to } \\
\text { the place }\end{array}$} & feeling of home & 8.7 & 7.1 & 6.3 & 6.9 & 7.8 & 5.4 & 5.5 & 5.5 & 5.4 & 5.2 & 8.0 & 5.9 & 7.3 \\
\hline & 'good address' & 7.7 & 8.0 & 7.7 & 7.4 & 8.5 & 6.5 & 6.2 & 5.5 & 6.4 & 5.0 & 8.7 & 7.5 & 7.5 \\
\hline & $\begin{array}{l}\text { 'longtime resi- } \\
\text { dency' }\end{array}$ & 7.4 & 6.7 & 7.8 & 7.7 & 7.1 & 4.0 & 8.1 & 6.2 & 5.8 & 7.7 & 8.5 & 8.3 & 7.4 \\
\hline & $\begin{array}{l}\text { relationship } \\
\text { with the neigh- } \\
\text { bours }\end{array}$ & 7.9 & 6.8 & 6.3 & 6.9 & 6.2 & 6.4 & 6.5 & 6.5 & 5.4 & 5.2 & 7.8 & 6.9 & 7.2 \\
\hline & $\begin{array}{l}\text { financial partici- } \\
\text { pation in the } \\
\text { courtyard mainte- } \\
\text { nance }\end{array}$ & 6.6 & 5.8 & 3.7 & 7.2 & 5.8 & 3.2 & 4.2 & 4.5 & 4.2 & 5.3 & 7.3 & 4.8 & 5.1 \\
\hline
\end{tabular}

Source: Czech Statistical Office 2016 


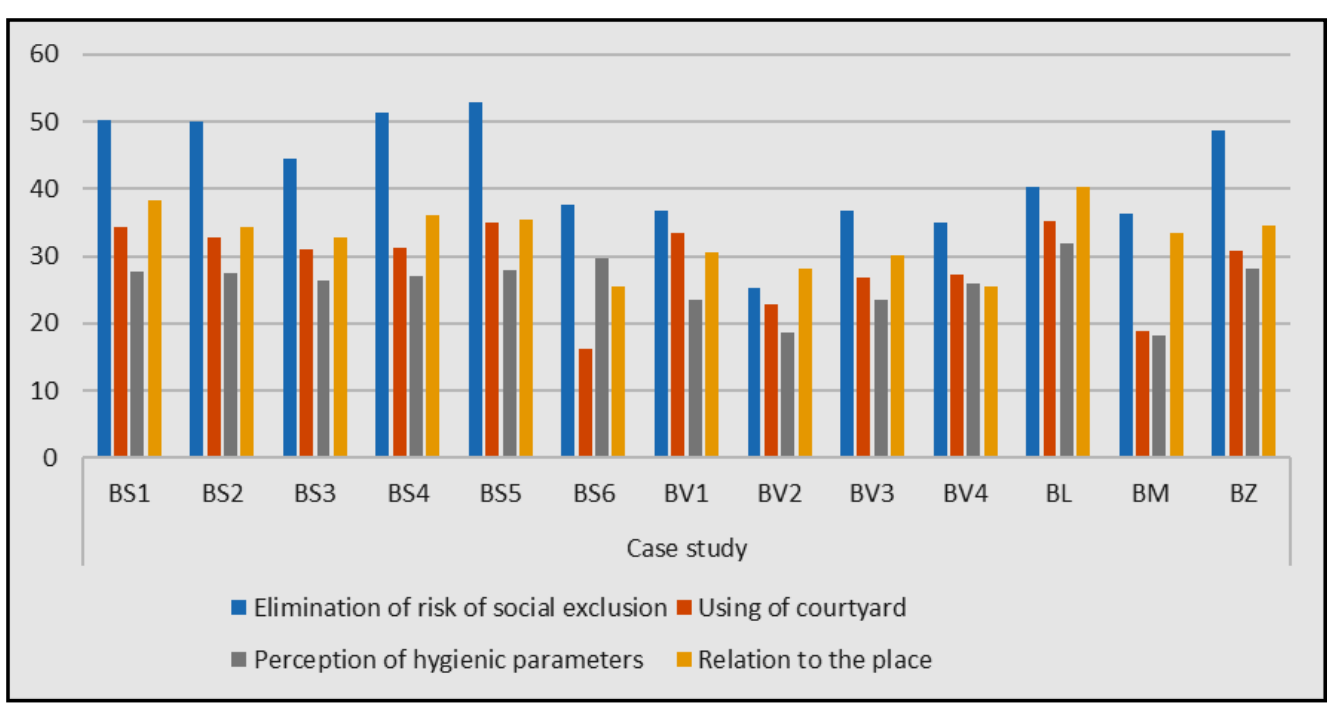

Fig. 8 - The sum of points in the framework indicators

results with the data about safety in public spaces in the city of Brno which are mostly evaluated as negative: 2.27 points. The city uses the scale 1-4 points where 4 points express the lowest satisfaction (Brno 2017). This study evaluates the safety in the courtyards mostly positively.

None of the surveyed spaces revealed significant problems with vandalism, drug users or similar pathological phenomena. Only the BV2 space seems to be problematic which is related to the large frequency of people in the vicinity of commercial spaces. Especially in the BS1 BS5 and BZ courtyards, the resulting framework indicator - the elimination of the risk of social exclusion is higher, as Fig. 8 shows (44.4 and more points).

Table 2 shows that some courtyards are characterized by a low diversity of activities as well as the low frequency of longer meetings with the neighbours, especially in BS6, BV2 and BM spaces. The BS6 and BV2 spaces show a high frequency of general use, which might be explained by the fact that BV2 serves as an entrance to the shops and BS6 serves for collecting the communal waste. The BM courtyard which is open to the street and does not provide privacy is used very rarely. The higher frequency of the meetings with the neighbours occurs among the residents in the BS1 - BS5, BV1, BV4 and BZ case studies. The questioned residents assume that the most balanced gender use is in the BS1, BS5 and BL spaces. The spaces that correspond the most to the residents needs are BL (8.0 points) and BS2 (7.5 points); on the contrary, the least 'corresponding spaces' are BV2 and BM (1.5 and 3.4 points). The BS1 - BS5, BV1, BL and BZ spaces are very well used overall as it is shown by the relevant framework indicator in Fig. 8 (30.7 and more points). It is worth mentioning the very good use of the BV1 space which departs from the line of similar, plain courtyards in the prefab housing estate. The BV1 space fulfils the function of the square in this housing estate.

Although the measurements of temperature and noise proved very similar hygienic parameters in all courtyards, it seems that in some cases the residents have a tendency to overestimate these qualities. An extreme example is highlighted by the questioned residents in Brno-Lesná housing estate $(\mathrm{BL})$. They assume that the vast, green space between the buildings strongly 
eliminates the high temperature, noise, smell and dust. It may be assumed that it is a psychological feeling from the residence in a space which is appointed as unique in the public discussions (Brněnský Deník [Brno Daily] 2009). The resulting framework indicator - the perception of the hygienic parameters in the $\mathrm{BL}$ courtyard - is above all others (32.0 points, Fig. 8). This result cannot be compared with the small isolated BS6 with no contact to the surroundings.

A good indicator of the quality of life is the residents' feeling that they live at a 'good address' (Table 2). This feeling is slightly stronger in the BS1 - BS5, BL, BM and BZ cases studies. The strongest feeling was indicated at BL (8.7 points) then in BS5 (8.5 points). The least 'good address' feeling was indicated in the housing estate Brno-Vinohrady (BV1 - BV4) where the values range from 5.0 to 6.4 points. The BS1 - BS5 and BL case studies exceed the other cases studies in other aspects. Here occurs the "longtime residency", and the good relation with the neighbours, while the residents (with the exception of BS3) are willing to pay extra for the maintenance of the courtyards. The highest sum of points in the framework indicator "relation to the place" (Fig. 8) was attained by the BL case study (40.3 points).

Generally, it may be stated that the respondents of the BS1 - BS5 case studies have shown a considerable unity in their positive opinions. The respondents in Brno-Vinohrady housing estate (BV1 - BV4) have shown surprisingly frequent positive stance contrary to expectations.

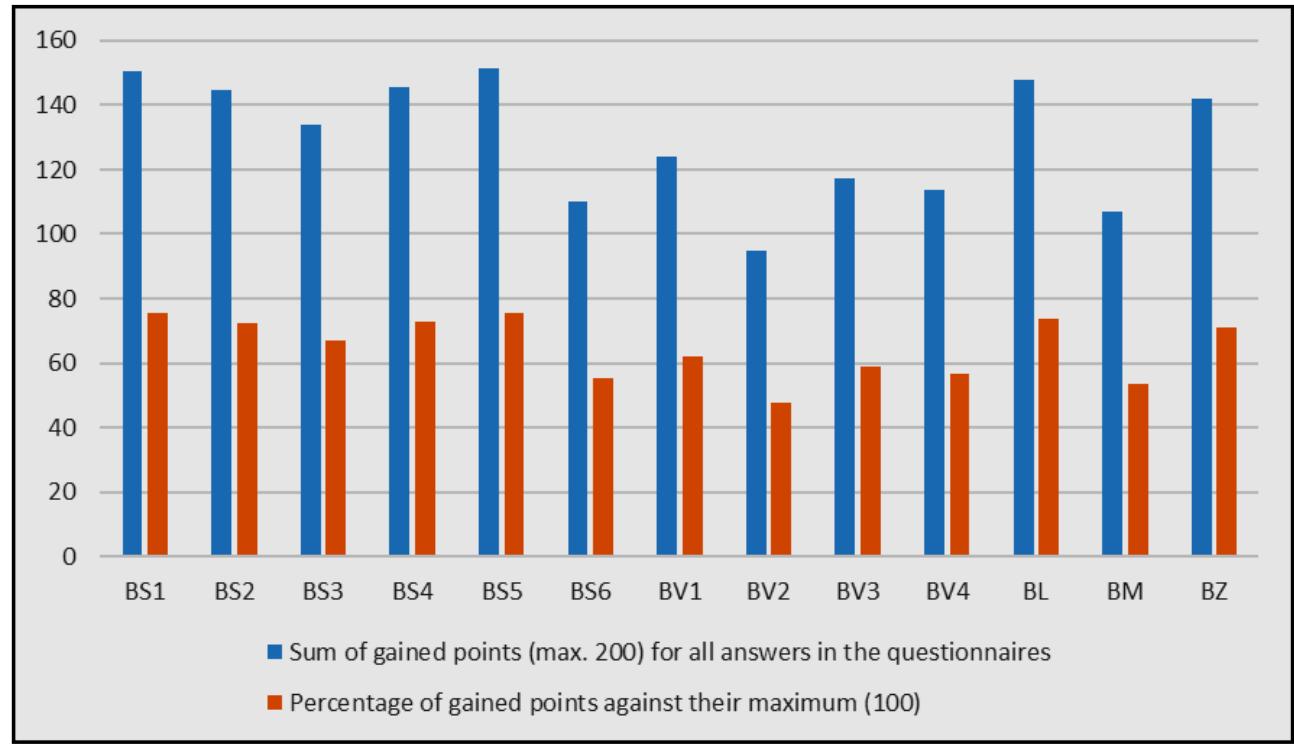

Fig. 9 - The overall satisfaction - the sum of gained points in all answers (in partial indicators, respectively framework indicators) - and the percentage of gained points against their maximum

Fig. 9 presents the sum of points gained in all the answers to the questions (partial, subsequent framework indicators) in the questionnaire survey, and it expresses the overall satisfaction of the residents living around the courtyards. The resulting satisfaction subjectively reflects the quality of life.

When comparing the results for each case study, it is obvious that the positive evaluation of the 
residents of the closed urban blocks (BS1, BS2, BS4, BS5) has a similar level, and more than 72 percent of the maximum points were obtained here (more than 144 points in the sum). The somehow lower evaluation was attained in the public accessible BS3 courtyard and also in the BS6 which is due to the small dimensions which cannot fulfil the function of courtyards (BS3: 66.9 percent of the maximum points / 133.7 points in the sum, BS6: 55.2 percent of the maximum points / 110.3 points in the sum).

A lower satisfaction was indicated especially by the residents of Brno-Vinohrady housing estate (BV1 - BV4), where less than 62.2 percent of the maximum points were obtained (less than 124.3 in the sum). The residents evaluated the open spaces as less significant with the exception of the central space BV1. The reason might be the fact that this attractive space has become a meeting place for the residents of the whole housing estate and thus it has become different from the other spatially and functionally similar spaces. The lowest satisfaction was expressed by the surveyed residents in the BV2 space which in fact serves as a pedestrian corridor connecting the stop of public transport and shops (BV2: 47.5 percent of the maximum points / 94.9 points in the sum).

A very high satisfaction with the courtyard was indicated by the residents of the building in Brno -Lesná housing estate (BL: 73.9 percent of the maximum points / 147.8 points in the sum). It can be observed that the main reason is an exceptionally strong subjective feeling that the space contributes to the qualities of the environment.

Also, the residents in Brno-Žebětín (BZ) appreciate the qualities of the courtyard. Its semiprivate character and partial closure enables a needed social control. The BZ courtyard is the smallest of the surveyed spaces (except the unusable BS6). The courtyard obtained 71 percent of the maximum points (142 points in the sum).

A less significant satisfaction was indicated by the residents of Brno-Majdalenky (BM: 53.4 percent of the maximum points / 106.8 points in the sum). The space without quality equipment and greenery is open to the street and thus it does not provide any barrier; in comparison with the other courtyards, it is on the margin of the residents' interest.

Additional notice: the basic parameters in the environmental and economic field confirmed good conditions for the development of the residents' community. The results are not shown in the tables but they are part of the following list. The following facts were indicated:

- in all the courtyards, the level of noise in the time of traffic peaks complies with the hygienic standards. The equivalent level of noise is in all cases less than $50 \mathrm{~dB}$, even in the courtyards BS1 - BS6 that are surrounded by intensive traffic. All courtyards slightly eliminate the summer maximum temperature attained in the surrounding streets. In all cases, the decrease of the temperature during the 4 hours afternoon period (sunny summer day) was between $0.7-1.8^{\circ} \mathrm{C}$. The largest difference was attained in BS1 - BS5 case studies, further BV3 and BV4. The BL case study showed the difference of $1.2^{\circ} \mathrm{C}$. The quality of air in the surveyed localities complied with the standards.

- the property prices of the buildings in BV1 - BV4, BL and BM localities reach the average price of the prices in the city. The prices of the real estate in BS1 - BS6 and BZ are slightly above the average, with the deviation up to $7 \%$ above the average prices in the city. In autumn 2016, the average city price of $1 \mathrm{~m}^{2}$ of flat was $45000 \mathrm{CZK}$.

\section{Discussion}

The article presents the results of a basic research that analyses the principal relationships between the residents' satisfaction and the courtyards in the post-socialist city of Brno. The research results are pilot data indicating relationships that should be verified on multiple case 
studies. Overall, the current results indicate the following principles:

a) The character of the courtyards influences the satisfaction of the residents and the quality of their life. A higher satisfaction is expressed by the residents living around the closed courtyards from the $19^{\text {th }}$ century (BS1 - BS5) and also from the post-socialist period (BZ); the differences in preferences are noticeable, compared especially to the typical socialist open prefab housing estate (BV1 - BV4) and the partially open courtyard from the post-socialist period (BM)

b) The spatial character of the courtyards, their closed or open form, generates the basic potential of the residential outdoor environment that influences the quality of life. This potential can be enhanced or reduced by the specific physical characteristics of the courtyards monitored in this study: equipment and greenery.

c) The demographic structure of the residents in the analysed areas in Brno is stable, balanced, so it can only minimally affect the results of the questionnaire survey of residents' satisfaction. The time period of the construction of the buildings and courtyards plays a minimal role in this sense. The unexpected result is that the demographic structure is stabilized in the analysed socialist prefab housing estates.

The results mentioned in the point a) imply in detail that the courtyards closed to the public, located in the structure of closed urban blocks, have the largest positive influence on the residents' community as they provide the qualities that the residents miss: quiet green space (BS1 - BS5). The buildings screen the courtyards with plenty of greenery from the street and its traffic. The quality of the environment in the courtyards is at the roughly same level as in the localities further from the city centre. The residents can meet their neighbours here frequently for a longer time. Similar effects can be described at the post-socialist courtyard BZ. The BS1 BS5 and BZ courtyards are considered as highly safe. There is no problem with vandalism, drug users or similar pathological phenomena, so the framework indicator - elimination of the risk of social exclusion - is high. There is a high social control in these courtyards. The small, underused courtyard in the same locality (as BS1 - BS5), the BS6, may cause that the adjoining buildings lose their residential value and people move away.

A slightly different situation is in the socialistic prefab housing estates whose basic idea was an open urban planning conception. The courtyards (open spaces between the residential buildings) are less screened, more public and moreover featureless. The residents tend to choose one of the uniform spaces as a place with a social function, and they use it as a square (BV1). The general impact of the courtyards on the residents' community development might be overall lower in the prefab housing estates. The vast, green spaces between the buildings in Brno-Lesná housing estate might be considered as a certain exception which in this study has been supported by only one case study $(B L)$ and it needs further verification. The extraordinary positive impact of the large space $(\mathrm{BL})$ with plenty of quality and varied greenery can be psychologically comparable with a stay in the nature environment (Koramaz and Türkoğlu 2018). But it must be also stated that the residents do not perceive the arguable economic requests of the area stemming from the maintenance costs of the space. The residents have some subjective 'knowledge of quality' which is possibly enhanced by the long-time public discussions about becoming a listed monument (Brněnský Deník [Brno Daily] 2009). The residents in the $B L$ case study (as in the other case studies with good image and environmental qualities: BS1 - BS5) expressed a very good "relation to the place". This result may lead to another interesting finding significant to the government of the city: a positively discussed image of the locality may raise its value among the public.

All the courtyards were analysed from the perspective of the character and quality of the greenery, and the recreational equipment. These aspects are important and they can affect the results as secondary factor which is mentioned in point b). It is obvious that the lack of greenery and recreational equipment in the BM courtyard along with its open spatial form negatively affects the monitored framework indicators when compared to other courtyards in 
the using of the courtyard and the hygienic parameters. An extremely large amount of untreated greenery could theoretically cause the feeling of danger, but none of the analysed courtyards has the potential to generate such effect. The courtyards were also described from the perspective of terrain morphology, but all the analysed courtyards lie in the plain or on a mild slope as in BZ, so they show no principal differences.

Also, the demographic structure of the surrounding buildings could influence the results. As mentioned in point c) - an important unexpected result of the study is connected with the demographic data obtained from the census in the prefab housing estates: the parameters of the analysed buildings (BV1 - BV4; and BL) are not significantly deviating from the average values recorded for the city or the state; none of these case studies represents a socially declining locality. On the contrary, in the Brno-Vinohrady housing estate (case studies BV1 BV4), the number of children significantly exceeds the seniors and there is a good assumption for further social development. Other results of the demographic analysis are here also unexpectedly good. Apart from the fact that there were significant investments to the open spaces (and buildings), the other reasons for good results are based on the facts lying out of our research area. The housing estate Brno-Vinohrady is equipped with quality greenery, numerous shops, schools and other service buildings and it offers good living conditions for the young families and seniors. This locality is undergoing continuous renovations. All these aspects create a quality city environment which provides good conditions for a high quality of life.

The results of this study may be of concern for the city of Brno which performs an analysis of satisfaction of the residents with the public spaces - streets and squares (Brno 2017). The results of this study which, on the contrary, analyses the spaces providing a certain level of privacy, are mostly opposing and positive. For the city, it may be interesting to enrich the existing own results with the results of this study (it is necessary to unify the method of points determination). Thus, the city can support the construction of specific residential areas which will provide a good quality of life within the complex area of the city - in the streets, squares and courtyards. The quality of life of the city's population is a very important instrument (argument) that can eliminate the intensive process of suburbanization in the Czech Republic. Before the potential application of the results, it is important to research more residential areas in Brno. Varied types of demographic structure and residential areas can appear in the city. A larger amount of data can also allow the theoretical generalization of the findings on the scale of the city, or even of the state or more states. This study builds on previous theoretical works mentioned in the references. However, this study is quite different and specific - it analyses the courtyards as a specific urban element in a post-socialist city.

Finally, it must be stated that the results of this research were limited by the following facts: the duration of the project was three years from the definition of the procedures till the evaluation of the results; it was difficult to organize the access to some of the buildings for the realization of the questionnaire survey; and the capacity of the team that realized the questionnaire survey consisted of only five persons. In order to get a wider database, future surveys should be organized by an agency. There is one more limitation of the existing research and one more reason for making the next research of multiple courtyards: the existing research analyses the statistical data from the national census performed in 2001 and 2011, but in 2021 the new census data for the demographic analysis will be accessible.

\section{Conclusions}

The results of this research indicate that we can identify a different influence of the different courtyards on the quality of life of the residents. The residents expressed their satisfaction with the courtyards in a questionnaire survey. This satisfaction subjectively reflects the quality of life. 
The results of this study need to be supported by further analyses. This study verifies whether there are some principles and relations between the character of the courtyards and the quality of life in the post-socialist city of Brno where the specific demographic structure in the prefab housing estates can play a role. The results indicate that the city of Brno can cope successfully with the heritage of the socialist past, and the prefab housing estates can become a standard housing for the new generation with standard or even above-standard demographic features.

Some general results can be summarized at this time. It is obvious that the courtyards are more valuable in the case they are part of closed urban blocks. The conception of closed urban blocks with usable courtyards creates quality conditions for housing and it can positively determinate the quality of life of the residents. From the social point of view, the studied courtyards have a more or less semi-private character which enables the social communication of the residents of the adjoining buildings. The closed courtyards, if they are clearly delimited, might give to the residents' community and to the local neighbourhood a higher level of privacy in comparison to the open spaces in the prefab housing estates.

As supposed, in addition to the character of the courtyards, other factors can also play a role in the development, planning and designing of the courtyards as part of the residential development: the costs of buildings, the transport connection to the surroundings, the aesthetic rules and the other architectural and urban planning requirements.

Regardless of these aspects, this study should show how just the character of the courtyards can influence the quality of life and how important the courtyards can be for the residents. With a slight exaggeration, the study may indicate that while the front façade of the residential building represents its display window, the courtyard might be seen as an outdoor living room used by the residents and by the neighbours.

\section{Acknowledgements}

This article was supported by the research project entitled 'The Importance of Open Space for Sustainable Urban Development', GAČR 15-05237S. The project was funded by the Czech Science Foundation (GAČR). The article presents an important outcome of the project.

\section{References}

ABASS Z. I., TUCKER R. (2018), Residential satisfaction in low-density Australian suburbs: The impact of social and physical context on neighbourhood contentment, Journal of Environmental Psychology 56, 36-45.

AGER R. D. (2008), Public housing residents making their courtyard safe from drugs, Journal of Social Work Practice in the Addictions 8 (1), 95-115.

ALAM D. W., AMIN A. (2018), Quality of Life and Well-Being Ranking of Selected Districts of Khyber Pakhtunkhwa, Pakistan, Social Indicators Research 137 (2), 527-537.

ALA-MANTILA S., HEINONEN J., JUNNILA S., SAARSALMI P. (2018), Spatial nature of urban well-being, Regional Studies 52 (7), 959-973.

ANDREWS M., GATERSLEBEN B. (2010), Variations in perceptions of danger, fear and preference in a simulated natural environment, Journal of Environmental Psychology 30 (4), 473-481.

BARAN P. K., TABRIZIAN P., ZHAI Y., SMITH J. W., FLOYD M. F. (2018), An exploratory study of perceived safety in a neighborhood park using immersive virtual environments, Urban Forestry \& Urban Greening 35, 72-81. 
BARTON H., GRANT M. (2015), Retrofitting suburbia for health: Scenarios for neighbourhood planning, in: Barton H., Thompson S., Burgess S., Grant M. (eds.), The Routledge Handbook of Planning for Health and Well-Being: Shaping a Sustainable and Healthy Future, Routledge, Abingdon, pp. 225-238.

BENKŐ M. (2015), Budapest's large prefab housing estates: Urban values of yesterday, today and tomorrow, Hungarian Studies 29 (1-2), 21-36.

BOWLER D. E., BUYUNG-ALI L., KNIGHT T. M., PULLIN A. S. (2010), Urban greening to cool towns and cities: A systematic review of the empirical evidence, Landscape and Urban Planning 97 (3), 147-155.

BRNĚNSKÝ DENÍK [BRNO DAILY] (2009), Z Lesné má být památková zóna [BrnoLesná to become a protected zone], Available at: http://brnensky.denik.cz/zpravy_region/zlesne-ma-byt-pamatkova-zona20091105.html (accessed on 24 November 2017).

BRNO (2010), Kvalita ovzduší [Air quality], Available at: https://ovzdusi.brno.cz/ (accessed on 14 September 2017).

BRNO (2017), Spokojenost obyvatel [Inhabitant's satisfaction]. Indikátorová soustava [Indicators system], Available at: https://www.brno.cz/strategie/indikatorova-soustava/ indikatorova-soustava/?pg=edit\&p_id=30 (accessed on 20 January 2018).

CHAPIN R. (2011), Pocket neighbourhoods, Taunton Press, Newtown.

CHIANG Y.-C., LI D., JANE H.-A. (2017), Wild or tended nature? The effects of landscape location and vegetation density on physiological and psychological responses, Landscape and Urban Planning 167, 72-83.

COMSTOCK N., DICKINSON L. M., MARSHALL J. A., SOOBADER M.-J., TURBIN M. S., BUCHENAU M., LITT J. S. (2010), Neighborhood attachment and its correlates: Exploring neighborhood conditions, collective efficacy, and gardening, Journal of Environmental Psychology 30 (4), 435-442.

COYLE S. (2011), Sustainable and Resilient Communities: A Comprehensive Action Plan for Towns, Cities, and Regions, John Wiley \& Sons, New Jersey.

CRAWFORD A., FLINT J. (2009), Urban safety, anti-social behaviour and the night-time economy, Criminology \& Criminal Justice 9 (4), 403-413.

DA SILVA E. A. P. C., OLIVEIRA L., PINTO COSTA DA SILVA P., ARAÚJO B., DE OLIVEIRA CAMINHA I., DE FREITAS C. M. S. M. (2012), Society, culture, and health motivation in the use of public space for leisure, Movimento 18 (1), 171-188.

DOUGLAS O., RUSSELL P., SCOTT M. (2018), Positive perceptions of green and open space as predictors of neighbourhood quality of life: implications for urban planning across the city region, Journal of Environmental Planning and Management, 1-21.

EUROSTAT (2013), Quality of life (QOL), Available at: https://ec.europa.eu/eurostat/ web/gdp-and-beyond/quality-of-life (accessed on 14 September 2017).

FOSTER S., GILES-CORTI B., KNUIMAN M. (2010), Neighbourhood design and fear of crime: A social-ecological examination of the correlates of residents' fear in new suburban housing developments, Health \& Place 16 (6), 1156-1165.

FOSTER-FISHMAN P. G., CANTILLON D., PIERCE S. J., VAN EGEREN L. A. (2007), Building an active citizenry: the role of neighborhood problems, readiness, and capacity for change, American Journal of Community Psychology 39 (1-2), 91-106.

FOWLER C. S. (2016), Segregation as a multiscalar phenomenon and its implications for neighbourhood-scale research: the case of South Seattle 1990-2010, Urban Geography 37 (1), 1-25.

FRANCIS M. (1989), Control as a dimension of public-space quality, in: Altman I., Zube

E. (eds.), Public Places and Spaces, Plenum Press, New York, pp. 147-172.

GRINDE B., NES R. B., MACDONALD I. F., WILSON D. S. (2018), Quality of Life in Intentional Communities, Social Indicators Research 137 (2), 625-640.

IÑIGO J., MACE A. (2018), The suburban perimeter blocks of Madrid 10 years on: how residents' level of satisfaction relates to urban design qualities, Planning Perspectives, 1-23. 
JAYNE M., HOLLOWAY S. L., VALENTINE G. (2006), Drunk and disorderly: Alcohol, urban life and public space, Progress in Human Geography 30 (4), 451-468.

JIANG B., CHANG C.-Y., SULLIVAN W. C. (2014), A dose of nature: Tree cover, stress reduction, and gender differences, Landscape and Urban Planning 132, 26-36.

KORAMAZ E. K., TÜRKOĞLU H. (2018), Measuring and Understanding Urban Parks' Contribution to Quality of Life in Istanbul, Social Indicators Research 138 (1), 335-351.

LI X., ZHANG C., LI W. (2015), Does the Visibility of Greenery Increase Perceived Safety in Urban Areas? Evidence from the Place Pulse 1.0 Dataset, ISPRS International Journal of Geo-Information 4 (3), 1166-1183.

LOVEJOY K., HANDY S., MOKHTARIAN P. (2010), Neighborhood satisfaction in suburban versus traditional environments: An evaluation of contributing characteristics in eight California neighborhoods, Landscape and Urban Planning 97 (1), 37-48.

LOW C.-T., STIMSON R., CHEN S., CERIN E., WONG P. P.-Y., LAI P.-C. (2018), Personal and Neighbourhood Indicators of Quality of Urban Life: A Case Study of Hong Kong, Social Indicators Research 136 (2), 751-773.

MADGE C. (1997), Public parks and the geography of fear, Tijdschrift voor economische en sociale geografie 88 (3), 237-250.

MAK B. K. L., JIM C. Y. (2018), Examining fear-evoking factors in urban parks in Hong Kong, Landscape and Urban Planning 171, 42-56.

MARTINEZ J. (2018), Mapping Dynamic Indicators of Quality of Life: a Case in Rosario, Argentina, Applied Research in Quality of Life, 1-22.

PERUCCA G. (2018), Residents' Satisfaction with Cultural City Life: Evidence from EU Cities, Applied Research in Quality of Life, 1-18.

SÁNCHEZ Á., CHICA-OLMO J., JIMÉNEZ-AGUILERA J. DE D. (2018), A Space-Time Study for Mapping Quality of Life in Andalusia During the Crisis, Social Indicators Research 135 (2), 699-728.

SENLIER N., YILDIZ R., AKTAŞ E. D. (2009), A Perception Survey for the Evaluation of Urban Quality of Life in Kocaeli and a Comparison of the Life Satisfaction with the European Cities, Social Indicators Research 94 (2), 213-226.

SIRGY M. J., CORNWELL T. (2002), How neighborhood features affect quality of life, Social Indicators Research 59 (1), 79-114.

SLAVUJ L. (2012), Evaluacija kvalitete urbanoga susjedstva - prednosti i nedostaci neposrednoga životnog prostora, Sociologija i Prostor 50 (2), 183-201.

ŠTREIMIKIENE D. (2014), Comparative Assessment of Environmental Indicators of Quality of Life in Romania and Lithuania, Economics \& Sociology 7 (1), 11-21.

SUGIYAMA T., THOMPSON C. W., ALVES S. (2009), Associations between neighbourhood open space attributes and quality of life for older people in Britain, Environment and Behavior 41 (1), 3-21.

TAYLOR A. F., WILEY A., KUO F. E., SULLIVAN W. C. (1998), Growing up in the inner city: Green spaces as places to grow, Environment and Behavior 30 (1), 3-27.

VALENTINE G., MCKENDRICK J. (1997), Children's outdoor play: Exploring parental concerns about children's safety and the changing nature of childhood, Geoforum 28 (2), 219235.

VASILEVSKA L. (2012), Towards more User-Friendly Public Open Space in Low-rise High Density Housing Areas, Proceedings of the 1st International Conference on Architecture \& Urban Design, 1-10.

VIDOVIČOVÁ L., GALČANOVÁ L., PETROVÁ KAFKOVÁ M., SÝKOROVÁ D. (2014), Stáři ve městě, město $v$ životě seniorü [Old people in cities, cities in old people's lives], SLON, Brno.

WEBER N., HAASE D., FRANCK U. (2014), Traffic-induced noise levels in residential urban structures using landscape metrics as indicators, Ecological Indicators 45, 611-621. 
Maxmilian WITTMANN, Gabriel KOPÁČIK, Antonín VAISHAR, Marcela PETROVÁ KAFKOVÁ, Pavla KILNAROVÁ

ZHANG D. (2013), Courtyard housing and cultural sustainability: theory, practice, and product, Ashgate, Burlington.

ZULAICA L., ORIOLANI F. (2018), Quality of Life and Habitability Conditions in PeriUrban Areas of Southern Mar del Plata, Argentina: a Multimethod Study, Applied Research in Quality of Life, 1-25.

Initial submission: 16.05 .2018

Revised submission: 12.10 .2018

Final acceptance: 01.11.2018

Correspondence: Department of Urban Design, Faculty of Architecture, Brno University of Technology, Poříči 273/5, 63900, Brno, Czech Republic.

Email: wittmann@fa.vutbr.cz 